\title{
Osellaeus bonvouloiri occidentalis ssp. nov. from the Vercors (France) - an alpine element at its distributional limits (Coleoptera, Apionidae)
}

\section{Christoph GERMANN}

Zoological Museum, University of Zürich, Winterthurerstrasse 190, CH-8057 Zürich, Switzerland.E-mail: germann.christoph@gmail.com

Osellaeus bonvouloiri occidentalis ssp. nov. from the Vercors (France) an alpine element at its distributional limits (Coleoptera, Apionidae). Osellaeus bonvouloiri occidentalis ssp. nov. was discovered in the Vercors, France. This remarkable finding on low altitude represents the most western site within the known distribution area of the nominal species.

Keywords: Coleoptera - Apionidae - Osellaeus - taxonomy - endemism alpine species - subspecies - isolation - Western Alps.

\section{INTRODUCTION}

Osellaeus bonvouloiri (Brisout, 1880) is distributed in the subalpine and alpine zone from 1600-3100 m in the central and western Alps of Italy, Switzerland and France. In Italy, the species is recorded from Veneto, Lombardia, Valle Aosta, and Piemonte (Abbazzi \& Osella, 1992). In Switzerland it is known from Berner Oberland, where the locus typicus (Brienzer Rothorn) is situated, furthermore from Waadt, Wallis, and Ticino (Scherler, 1995). It should be mentioned at this point that the altitude of $3000 \mathrm{~m}$ indicated by Brisout (1880: 232) is wrong, as the top of the Brienzer Rothorn just reaches $2350 \mathrm{~m}$. From France, records of $O$. bonvouloiri are known from Haute Savoie, Hautes Alpes (Briançonnais, Queyras), and Alpes-Maritimes (Tempère, 1978, Tempère \& Péricart, 1989).

Two subspecies have been described so far:

1. O. b. georgeli (Hoffmann, 1929). The description was based on specimens from Eymoutiers (France: Haute Vienne). The finding location as well as the circumstances of the capture are very doubtful (see Tempère, 1978: 224, Tempère \& Péricart, 1989: 347). Furthermore after Tempère \& Péricart (1989) there are no reliable differences to the nominal species, and the subspecies was listed as synonym to $O$. bonvouloiri. As a consequence Pelletier (2005) does not mention $O$. b. georgeli in his checklist anymore.

2. O. b. baldensis (Bellò, Meregalli \& Osella, 1980). The description was based on specimens from Telegrafo, Monte Baldo (Italy: Veneto) at the easternmost limit of the distribution area of $O$. bonvouloiri (Bellò, Meregalli \& Osella, 1980). Compared to the nominal species, $O . b$. baldensis is distinguishable after the authors (op. cit.) by the 
slender and longer rostrum, the more protruding eyes, and the strong first segment of the funiculus as well as the oval shaped, more flatted club. Generally, specimens of the type series are smaller, the antennae are more slender (gracile), the integument is shinier, and the aedeagi are rounded at the apex. Only the last two characters of $O . b$. baldensis are similar to those mentioned in the following description of $O$. bonvouloiri occidentalis ssp. nov.

\section{MATERIAL AND METHODS}

Collection took place on 16th of October 2001 on the Col de la Bataille, at the border of the Plateaux du Vercors in France. The new subspecies was captured by sifting mosses and tuffs of Saxifraga oppositifolia L. The biotope is characterised by rocky creeping of limestone.

The body size was measured laterally from the apex of the elytra to the eyes frontal margin (rostro excluso, r. e). The apex of the aedeagus was measured at the broadest point (B), and from there to the tip of the apex (L) as illustrated in Fig. 3b. The pictures were taken with a 4-megapixel digital camera (JVC) under a stereomicroscope (Leica MZ16). The images were modified with the program Auto-Montage (Synoptics) for best results in depth of sharpness, and then reworked using Adobe Photoshop version 10.0.1 (Adobe Systems Incorporated). The type material of $O . b$. occidentalis ssp. nov. is preserved in the following collections: Tiroler Landesmuseum Ferdinandeum Innsbruck, Austria (TLMF); Muséum d'histoire naturelle de Genève, Switzerland (MHNG); Naturhistorisches Museum Bern, Switzerland (NMBE); Natural History Museum Vienna, Austria (NHMW); collection Christoph Germann, Thun, Switzerland (cCG).

\section{TAXONOMIC PART}

Osellaeus bonvouloiri occidentalis ssp. nov.

Figs 1a-3a

Holotype: 1 đ: France, Vercors, Col de la Bataille, 1400 m, 16.10.2001, leg. Ch. Germann (MHNG).

PARATYPES: 5 to $\delta$ and $5 q q$, same indications as the holotype. $3 q q$ MHNG, 1 to and

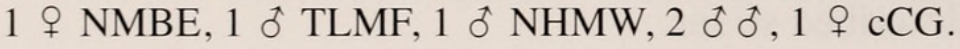

\section{DESCRIPTION}

Size (r.e): 1.7-2.4 mm (o 1.7-2.3 mm, ㅇ 2.1-2.4 mm)

Body colour: black with a metallic shine. Elytra are dark bluish to greenish coloured.

Head, rostrum and antennae: punctuated, some points with tiny (hardly visible) short bright recumbent hairs. The spaces in between the points are mostly wider than the diameter of a point, weakly chagrined so that the integument is still shiny. Antennae are strong and short, inserted at the end of the first third of the rostrum. The last two segments of antennal funiculus are transverse. The antennal club is big, almost three times as wide as the last antennal segment.

Pronotum: (Fig. 2a) index (L/B): 0.91-1.07. About as long as wide, coneshaped, widest at the base. As far as the surface concerns, same features as head and 

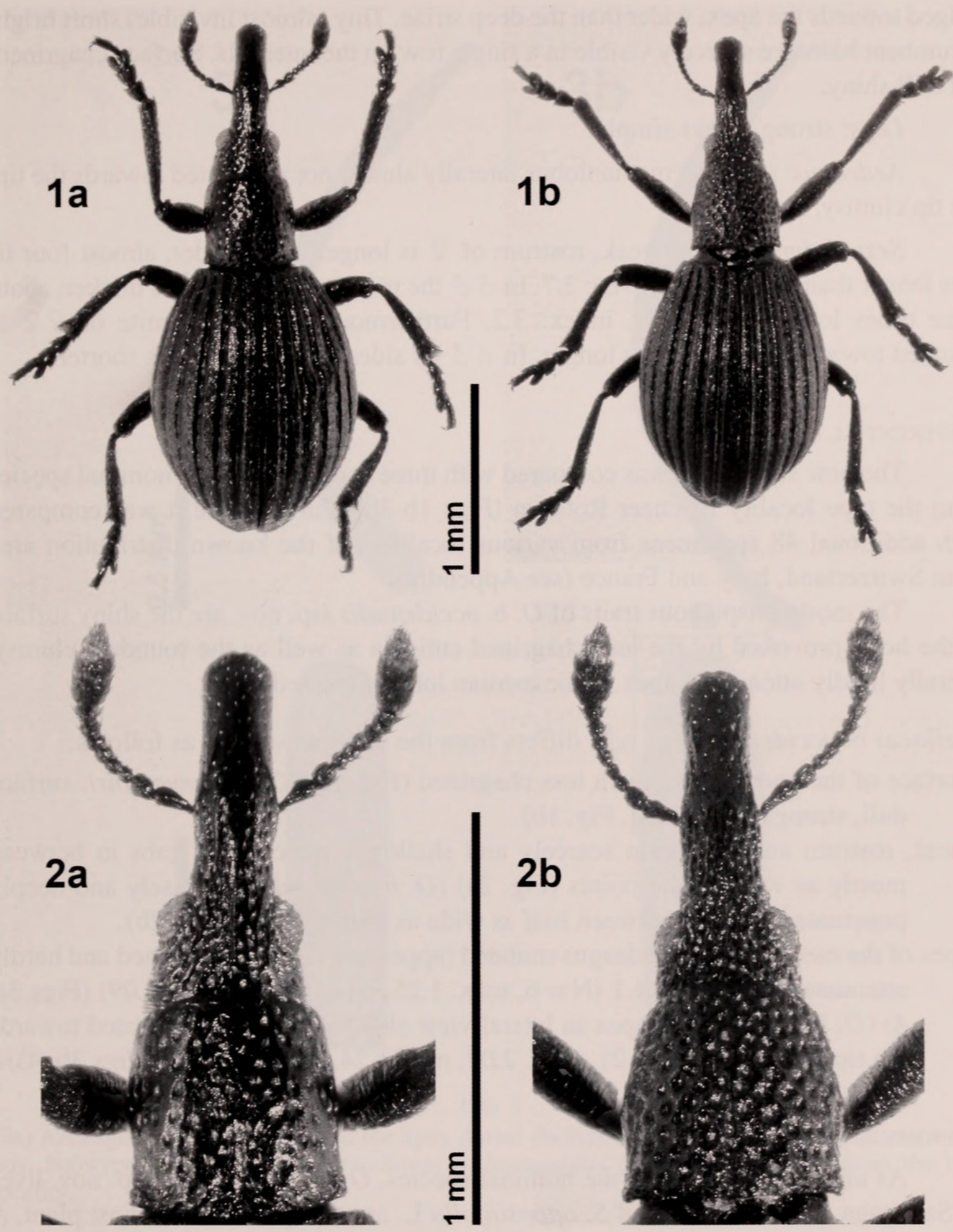

FIGS 1-2

(1a) Osellaeus b. occidentalis ssp. nov. holotype. (1b) Osellaeus b. bonvouloiri (Ch. Brisout, 1880) from the type locality. (2a) Pronotum, head and rostrum from Osellaeus b. occidentalis ssp. nov. holotype. (2b) Same from Osellaeus b. bonvouloiri (Ch. Brisout, 1880) from the type locality.

rostrum, before the almost invisible scutellum slightly carinated a fourth till a third of the total length.

Elytra: without humeral callus (apterous), laterally strongly rounded, widest in or behind the middle, sometimes trapezoid-shaped. Intervals flatted at the disc, more 
bulged towards the apex, wider than the deep striae. Tiny (almost invisible) short bright recumbent hairs are scarcely visible in a single row on the intervals. Surface chagrined, but still shiny.

\section{Legs: strong, claws simple.}

Aedeagus: (Fig. 3a) medianlobus laterally almost not attenuated towards the tip, the tip clumsy, rounded.

Sexual dimorphism: weak, rostrum of $q$ is longer and slender, almost four times longer than wide, index $(\mathrm{L} / \mathrm{B}): 3.7$. In $\delta$ the rostrum is shorter and thicker, about three times longer than wide, index: 3.2. Furthermore the fifth sternite of $q q$ is rounded towards the apex, thus longer. In $\delta \hat{\sigma}$ its sides are parallel, thus shorter.

\section{DIFFERENTIAL DIAGNOSIS}

The new subspecies was compared with three specimens of the nominal species from the type locality Brienzer Rothorn (Figs 1b-3b). Furthermore it was compared with additional 48 specimens from various localities of the known distribution area from Switzerland, Italy and France (see Appendix).

The most conspicuous traits of $O . b$. occidentalis ssp. nov. are the shiny surface of the body provoked by the less chagrined cuticula as well as the rounded, clumsy, laterally hardly attenuated apex of the median lobe of the aedeagus.

Osellaeus $b$. occidentalis ssp. nov. differs from the nominal species as follows:

- surface of the body shiny, much less chagrined (Fig. 1a) (O. b. bonvouloiri: surface dull, strongly chagrined, Fig. 1b).

- head, rostrum and pronotum scarcely and shallowly punctuated, gabs in between mostly as wide as the points (Fig. 2a) (O. b. bonvouloiri: densely and deeply punctuated, gabs in between half as wide as points or less, Fig. 2b).

- apex of the medianlobe of aedeagus rounded (appearing clumsy, thickened and hardly attenuated, tip: $\mathrm{L} / \mathrm{B}=1.1(\mathrm{~N}=6$, max. 1.25, min. 1.0, std. dev. 0.09) (Figs 3a, 4) (O. b. bonvouloiri: apex in lateral view slender, strongly attenuated towards the tip, L/B: $=1.6(\mathrm{~N}=21$, max. 2.08, min. 1.24, std. dev. 0.26) (Figs 3b, 4)).

\section{BIONOMY}

As already known from the nominal species, $O . b$. occidentalis ssp. nov. lives on Saxifraga. The sifted tuffs of S. oppositifolia L. are thought to be the host plant. A special fact concerning ecology is the comparatively low altitude $(1400 \mathrm{~m})$ where the new taxon was found, as well as the late appearance time (October). The latter could also be an artefact, as it is not that efficient concerning weather conditions to conduct excursions at higher altitudes that late in the year. The author already collected specimens of the nominal species in late September nearby Zermatt (see Appendix).

\section{DERIVATIO NOMINIS}

The new subspecies occidentalis is named after its most western finding location $($ Latin: occident $=$ western $)$. 


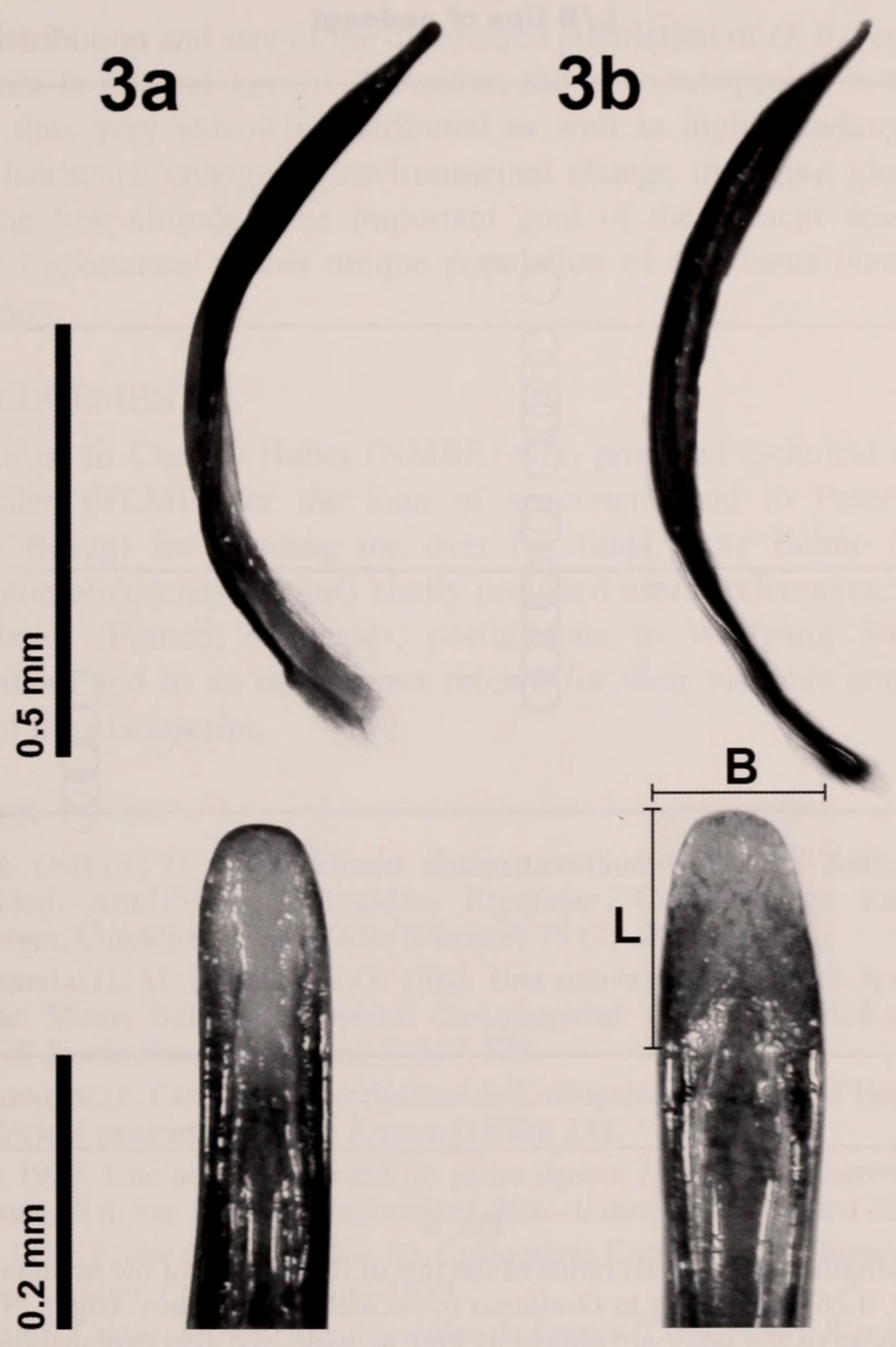

FIG. 3

(3a) Aedeagus, lateral (above) and the apex dorsal (below) from Osellaeus $b$. occidentalis ssp. nov. holotype. (3b) Same from Osellaeus b. bonvouloiri (Ch. Brisout, 1880) from the type locality.

\section{DISCUSSION}

The discovery of $O . b$. occidentalis ssp. nov. in the Vercors is at the very margin of the main distribution area. The closest finding locations up to date of the nominal species are the specimens from Dévoluy, Tête de la Cluse (Hautes Alpes) more than sixty kilometres eastern. As already shown with the ssp. baldensis by the respective authors, the tendency to differentiate is typical for the apterous, thus much immobile, and ecologically such specialised alpine element $O$. bonvouloiri.

The speciation process of $O$. $b$. occidentalis ssp. nov. is explained with its isolation from the main population of the nominal species. The illustrated morpho- 


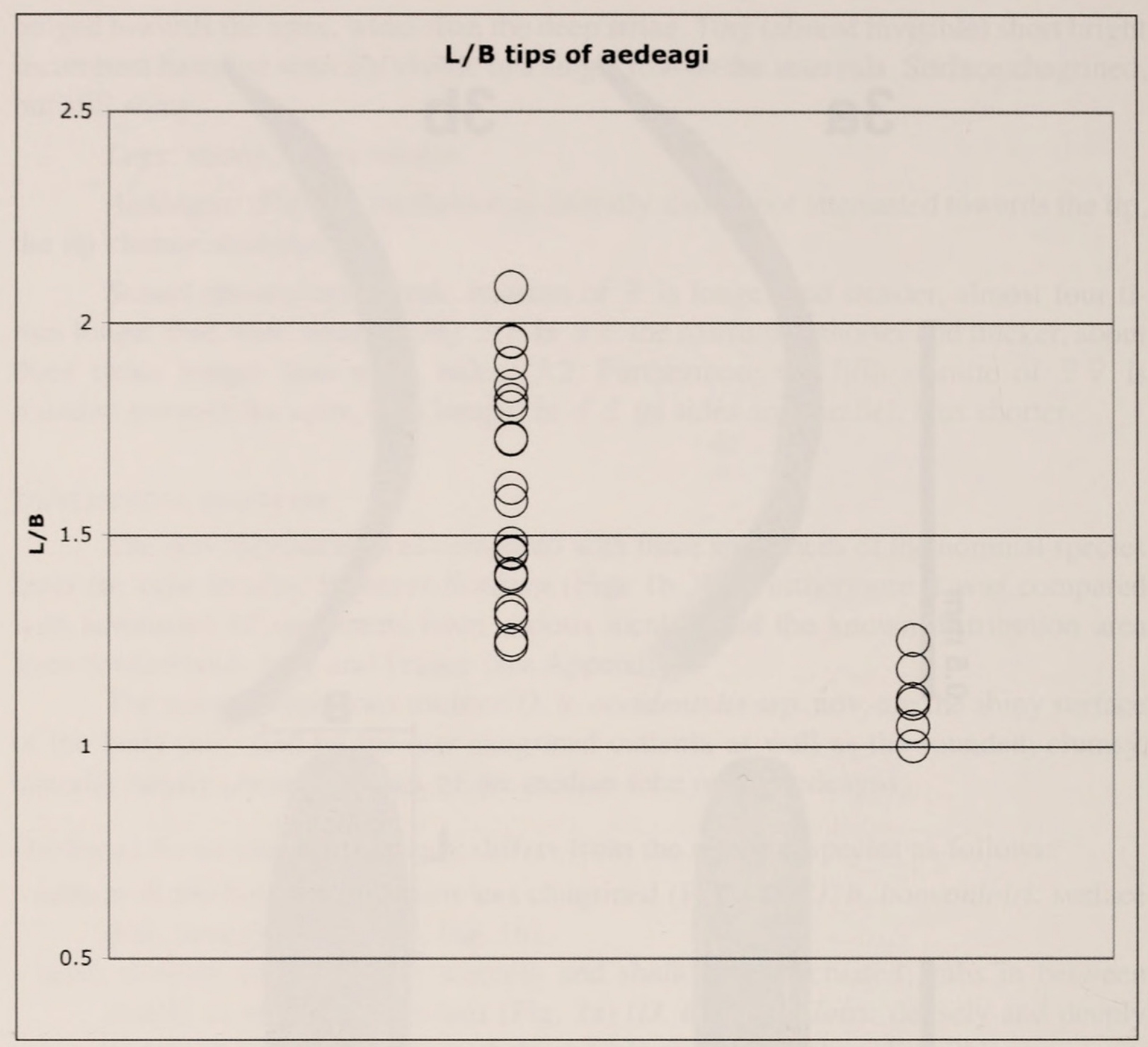

FIG. 4

Graph showing length to wide (L/B) ratios of the tips of the aedeagi of the nominal species (left, $\mathrm{N}=21$, std. dev. 0.26) in contrast to Osellaeus b. occidentalis ssp. nov. (right, $\mathrm{N}=6$, std. dev. 0.09 ), whereas those of the latter are almost as long as wide, see also explanations in the differential diagnosis.

logical differences are classified as objective verifiable indication of a genetic divergence towards the nominal species. However, this should be verified directly with molecular methods. Unfortunately this was not possible within the present study. If the new taxon is isolated in respect of reproduction, in the sense of the biological species concept, this obviously cannot be answered coherently. Although a certain sign was found in the different morphology of the aedeagus, a functional structure that is well known to be a key character in taxonomy. Because of the uncertainty of existing reproductive barriers, and based on comparatively small morphological differences, the new taxon is preliminarily classified as subspecific. 


\section{CONSERVATION}

The distribution and size of the discovered population of $O . b$. occidentalis ssp. nov. in Vercors is not yet known. However, the new subspecies is thought to be isolated, and thus very narrowly distributed as well as highly endangered through hypothetical landscape change or environmental change including global warming, because of the low altitude. One important goal of the present description is to underline the importance of this unique population of Osellaeus bonvouloiri occidentalis ssp. nov.

\section{ACKNOWLEDGEMENTS}

Thanks go to Charles Huber (NMBE) who provided technical equipment, to Manfred Kahlen (TLMF) for the loan of specimens and to Peter Sonderegger (Switzerland, Brügg) for handing me over his finds. Lutz Behne (Senckenberg, Deutsches Entomologisches Institut) kindly provided useful references. I am thankful to Jean Pelletier (France, Monnaie), posthumous to Wolfgang Suppantschitsch (Austria, Vienna), and to an anonymous referee for their valuable comments on an earlier draft of the manuscript.

\section{REFERENCES}

AbBazZI, P. \& Osella, G. 1992. Elenco sistematico-faunistico degli Anthribidae, Rhinomaceridae, Attelabidae, Apionidae, Brentidae, Curculionidae italiani (Insecta, Coleoptera, Curculionoidea). Redia (Firenze) 75 (2): 267-414.

Bellò, C., Meregalli, M. \& Osella, G. 1980. Una nuova sottospecie di Apion bonvouloiri Bris. del Monte Baldo (Coleoptera: Curculionidae: Apionidae). Bolletino del Museo Civico di Storia Naturale, Verona 7: 519-525.

Brisout de BaRneville, CH. 1880. Descriptions de Coléoptères nouveaux d`Europe. Annuaires de la Société entomologique de France (1880): 232.

Hoffmann, A. 1929. Une nouvelle variété du genre Apion: (Perapion) Bonvouloiri Ch. Bris., var. Georgeli n. var. (Col. Curculionidae). Miscellanea Entomologica 32: 43-44.

Hoffmann, A. 1958. Faune de France, No. 62. Coléoptères Curculionides. 3ième partie. Editions Paul Lechevalier, Paris, pp. 1210-1839.

Pelletier, J. 2005. Catalogue des Curculionoidea de France (Coleoptera). Biocosme Mésogéen, Nice 21 (3): 75-147.

SCHERLER, P. 1995. Répartition actuellement connue en Suisse de quelques Coléoptères Curculionides d`altitude. Mitteilungen der Schweizerischen Entomologischen Gesellschaft 68: 179-187.

Tempère, G. 1978. Catalogue des Coléoptères Curculionidae de France. Essai de mise à jour critique. Sixième partie. Entomops 46: 213-232.

Tempère, G. \& Pericart, J. 1989. Faune de France 74. Coléoptères Curculionidae 4ième Partie. Fédération française des sociétés de sciences naturelles, Paris, $534 \mathrm{pp}$. 


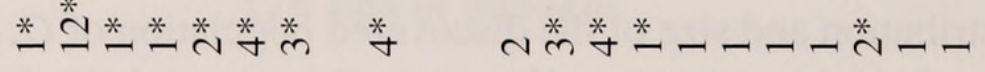
in

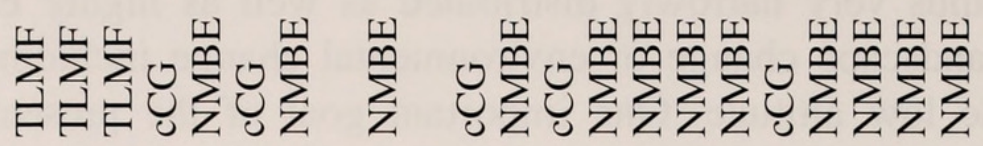

ㅇํำสิช

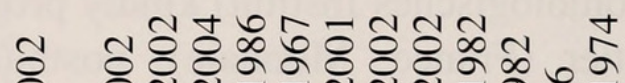

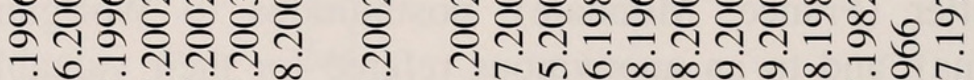
a.

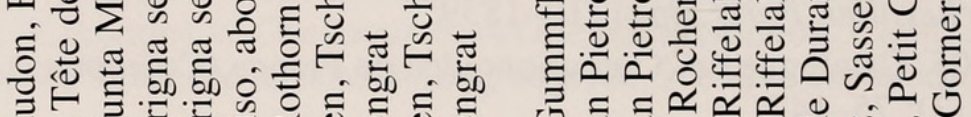

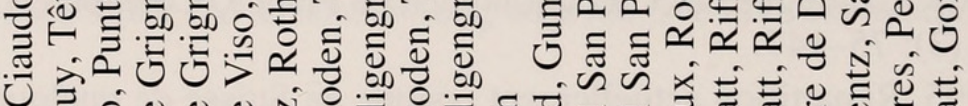

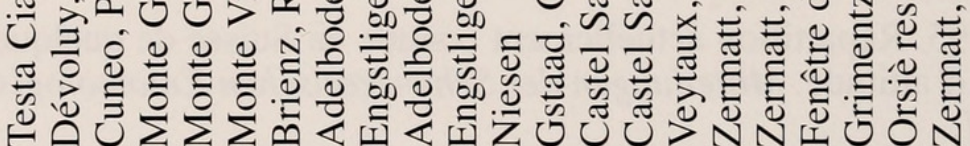

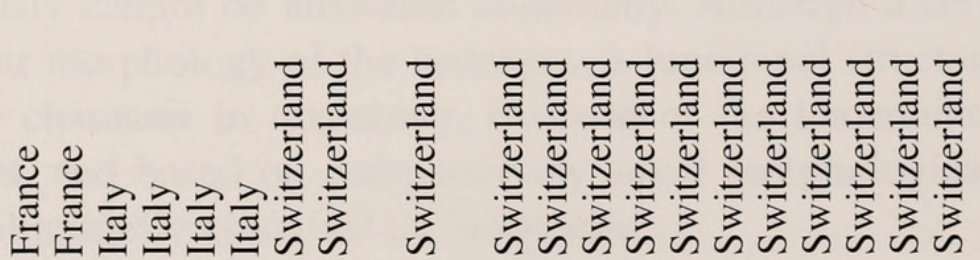




\section{$2 \mathrm{BHL}$ Biodiversity Heritage Library}

Germann, Christoph. 2010. "Osellaeus bonvouloiri occidentalis ssp. nov. from the Vercors (France) - an alpine element of its distributional limits (Coleoptera, Apionidae)." Revue suisse de zoologie 117, 3-10.

https://doi.org/10.5962/bhl.part.117583.

View This Item Online: https://www.biodiversitylibrary.org/item/148549

DOI: https://doi.org/10.5962/bhl.part.117583

Permalink: https://www.biodiversitylibrary.org/partpdf/117583

\section{Holding Institution}

American Museum of Natural History Library

\section{Sponsored by}

BHL-SIL-FEDLINK

\section{Copyright \& Reuse}

Copyright Status: In copyright. Digitized with the permission of the rights holder.

Rights Holder: Muséum d'histoire naturelle - Ville de Genève

This document was created from content at the Biodiversity Heritage Library, the world's largest open access digital library for biodiversity literature and archives. Visit BHL at https://www.biodiversitylibrary.org. 